DOI: https://doi.org/10.47405/mjssh.v6i10.1124

\begin{tabular}{|c|c|}
\hline 4.581 & Malaysian Journal of Social Sciences and Humanities (MJSSH) \\
\hline $\begin{array}{l}\text { Malaysian Journal of } \\
\text { Social cciences and }\end{array}$ & Volume 6, Issue 10, October 2021 \\
\hline (MJ-SSH) & e-ISSN : 2504-8562 \\
\hline & $\begin{array}{l}\text { Journal home page: } \\
\text { www.msocialsciences.com }\end{array}$ \\
\hline
\end{tabular}

\title{
Psychological Perspectives Toward Student's Incompetency in Foreign Language Course
}

\section{Abdul Rashid Abdul Aziz ${ }^{1}$, Rezki Perdani Sawai', Shahirah Sulaiman², Khairul Anuar Rahimi1, Joki Perdani Sawai³, Muhammad Nubli Abdul Wahab4}

\author{
1Faculty of Leadership and Management, Universiti Sains Islam Malaysia (USIM), Malaysia \\ ${ }^{2}$ Centre of Tamhidi, Universiti Sains Islam Malaysia (USIM), Malaysia \\ ${ }^{3}$ Faculty of Psychology and Education, Universiti Malaysia Sabah (UMS), Malaysia \\ ${ }^{4}$ Centre for Modern Language and Human Sciences, Universiti Malaysia Pahang, 26600 Pekan, Pahang, Malaysia
}

Correspondence: Abdul Rashid Abdul Aziz (rashid@usim.edu.my)

\begin{abstract}
Learning a foreign language enables learners to go further after graduation. In today's world, there is a need for students to be able to communicate in at least one foreign language so that they can function well globally. This study investigates learning the German language among engineering students who are taking a dual degree program in a public university in east coast Malaysia. The objectives of the study were: (a) to determine the students' attitude in learning German language; (b) gauge their understanding of the course in terms of materials and lessons used in learning the language; and (c) identify their motivation and performances taking German language. Using a descriptive research design, 60 students were involved as respondents in this study. Their responses to the researchers' questionnaire were gathered in a WhatsApp group called Success German Course (SGC). The results of the study indicated that students demonstrated moderate attitude in learning the course since some of them were eager to learn the language while others were not. Some students reported failing to understand the course in the use of the current materials and lessons. Although they showed positive attitude in learning the course, their performances, nevertheless, were not encouraging because they did not have sufficient time to learn the language. It is concluded that students need to learn study skills to help them to be more competence in foreign language proficiency. The overall findings implied that there is a possibility that the curricula need to be revisited to suit the learning needs of the students.
\end{abstract}

Keywords: Foreign language, motivation, student's incompetency

\section{Introduction}

According to the National Higher Education Strategic Plan Beyond 2020 (Ministry of Higher Education, 2007), third language proficiency is vital to develop human capital that drives the Keconomy and propel the country towards competitive innovation at the international level. The strategic plan encourages all higher learning institutions to provide a chance for students to be proficient in a third language such as Tamil, Mandarin, French, Japanese, German or Spanish. To ensure the success of this plan, foreign languages are now offered at almost all public institutions of higher learning in Malaysia such as Universiti Malaya (UM), Universiti Putra Malaysia (UPM), Universiti Sains Malaysia (USM), Universiti Utara Malaysia (UUM), International Islamic University Malaysia 
(IIUM), Universiti Malaysia Sabah (UMS), Universiti Kebangsaan Malaysia (UKM), Universiti Teknologi Mara (UiTM) and Universiti Malaysia Sarawak (UNIMAS) (Ainol, Isarji \& Mohamad Sahari, 2007).

Learning a foreign language is an important requirement for today's students to face the challenges of the career world as well as mastery of knowledge in the world without boundaries. Furthermore, in the currents of globalization and the internet of things, the knowledge of foreign languages is an advantage to facilitate individual interaction. Proficiency in foreign languages such as English and Mandarin opens more job opportunities especially in the corporate sector (Hidayatul, 2018). According to Azizi (2018), in this era of globalization, people are advised to learn foreign languages as an added value in personal quality as language plays an important role worldwide. By mastering a foreign language, it will enable graduates to gain not only access to the most up-to-date technologies and information, but also to gain an advantage in an increasingly multicultural and diverse workplace, where more opportunities will be available to a workforce who is fluent in multiple languages. Language is an important tool for human communication. Without language, we cannot express our thoughts and expressions to others, and we cannot engage in societal activities for self-development (Di Pietro, 1994). Language is very important in education. For instance, Roy-Campbell and Qorro (1997) asserted that education is carried out largely through the medium of language, thus, language is very significant in the education process. Additionally, ADEA (2005) argues, "Language is not everything in education, but without language, everything is nothing in education". Language plays a crucial role in learning, and if the learner is handicapped in the language of instruction, then learning may not take place at all as the instructor or teacher and the learner will not be communicating (Malekela, 2003).

Learning a foreign language in institutions of higher learning may become as an option for students or an obligation requirement for some courses in university. Learning a foreign language is seen as an added value to university students who need to prepare themselves in facing a dynamic and borderless job market. Even though, it is known that learning foreign language in the education system in Malaysia is based on the purpose of communication. Nevertheless, it is difficult to learn the foreign language if there are psychological barriers and attitude constraints which can impede and disturb student's learning process in attaining language proficiency (Azman, 2010). This leads to a failure in mastering a foreign language as well as a loss of interest in learning the language. Thus, this study aims to investigates the factors of student's incompetency from psychological perspectives such as students' attitude in learning German language, course materials and lessons used in learning the language, as well as to identify their motivation and performances taking German language course. It is important for teachers, curriculum planners, and policy makers to know students' beliefs and attitudes toward foreign language learning (Ainol \& Isarji, 2009).

\section{Literature Review}

A large and growing body of literature has investigated the importance of foreign language courses at the university level. A study that was conducted among learners in New Zealand in learning Japanese as a foreign language found several reasons concerning their interest in learning a foreign language (de Burgh-Hirabe, 2019). The main reason stated was the integrative orientation because of the Japanese popular culture and traditional culture. These are the indirect reasons that make students want to learn Japanese language even though learning any foreign language is neither required nor widely valued in universities in New Zealand.

Another study was conducted to investigate the motivational factors among young language learners in an elementary school to learn foreign language. The study conducted by Oga-Baldwin et al. (2017) showed that there was an intersection of the classroom and the individual that provides motivation to the learner to learn a foreign language. Towards the end of the course, the quality of the students' motivation was developed due to their own self-motivation and the learning experiences they gained in the classroom. Moreover, requiring students to engage in various learning tasks with the support by their teachers indirectly led them to become autonomous learners (Oga-Baldwin et al., 2017). 
Motivation is described as a combination of effort and desire to achieve a language learning goal, as well as positive attitudes toward language learning (Ulfa \& Bania, 2019). Gardner and Lambert (1972) investigated the role of attitudes and motivation in second language acquisition (SLA), describing motivation as "the learner's ultimate aim or orientation" and attitude as "the learner's persistence in aiming for a goal" (Ellis, 1985; Patsy Lightbown et al., 2000). Two types of motivation were believed to be important in studying a second language. The two types of motivations are the integrative motivation and instrumental motivation. If an individual learns another language because he is interested in the people and culture of the target language or in order to communicate with people of another culture who speak it, the individual is said to be integratively motivated (Siti Khasinah, 2014). On the other hand, instrumental motivation is described as more functional and useful. For instance, a person learns a second language with the aims to pass an examination, get a better job, or getting into the right university (Siti Khasinah, 2014).

In addition, a study done by Ali and Darshini (2020) on degree students who learn English as a Second Language (ESL) showed that most of them were instrumentally motivated towards learning ESL. Meanwhile, Rubrecht and Ishikawa (2012) mentions that motivation to learn a second language indicates the degree to which a person works to learn the language because of the urge to do so, and the satisfaction they feel in a task. However, learners can be influenced by both types of motivation (Leila \& Firooz, 2015). For example, a person might be integratively oriented to learning the culture of the targeted community, but at the same time, instrumentally motivated to get a job at an international company.

In addition, another type of motivation highlighted by most studies are the intrinsic and extrinsic motivation. Intrinsic motivation was defined by Ryan and Deci (2000) as doing something because it is inherently interesting or enjoyable. This definition is similar to Pintrich (2000) definition of intrinsic motivation as a task that is carried out due to a person's experiences of enjoyment and interest when the individuals were asked to do something and not expecting any rewards in return.

On the contrary, extrinsic motivation is a task that is carried out when a person is doing something to receive a reward. Dornyei (1994) refers to extrinsic motivation as a task that individual does because of his external motivation comes from outside of him as the individual will obtain a reward (money) out of doing a task or improved grades when he does better in exams. For instance, extrinsically motivated individuals learn a second language to get job promotion.

Lei (2010) found that intrinsically motivated learners tend to perform better in a learning course and achieve higher grades compared to those learners who are externally motivated (Lei, 2010). Intrinsic motivation leads to greater success in learning a foreign language, especially in a long run (Siti Khasinah, 2014). However, there is some inconsistency with this argument. Hall (2011) argues learners should be encouraged by a mixture of both types of motivation. Hence, a learner may be "intrinsically motivated by the inherently enjoyable" (in example, the language environment) in order to achieve such goal (in example, passing an exam). Furthermore, Dornyei (2002) said the enthusiasm, dedication, and perseverance of the learner are the essential factors in determining the success or failure. Thus, based on these previous studies, the element of motivation in learning a foreign language is very crucial to determine student's success in their foreign language course.

A review of recent research on English language literacy in Malaysia shows a clear preference for presenting literacy as a collection of independent skills (Normazidah, Koo \& Hazita, 2012). In further, Ambigapathy (2006) mentioned that literacy is learnt as a set of skills and not as a social practice connected to various domains and communities of practices in the real world. A study done by Hazita Azman (1999) to examine socially embedded literacy events in rural areas. This study diverges from previous studies in Malaysia which relate literacy issue to deficiencies in the non-school environment and lesser cognitive abilities. This study revealed that the differences between communities, ethnic groups and socioeconomic status has less influencing effect on a rural child's literacy development.

On a different note, the Cambridge University Press (2021) indicates that the elements namely pedagogy, curricula, materials and assessment for students to be competent in learning a language. 
Figure 1 shows that competency-based in learning a language consists of 'Pedagogy' in that it supports teachers to ensure effective teaching and able to measure their students' communicative competency. In 'Curricula' the teachers need to identify the learning objectives and relate it to the real-world situations and contexts. Such is required so that students are able to learn useful language for their needs. 'Materials' is another important element in the competency-based approach in language learning. Exercises need to focus on giving communicative tasks and functional language skills. Also important is to integrate the learning of grammar and vocabulary in the exercises that are assigned to the students. Finally, 'Assessment' is the peak of all these elements. When assessing students, the cando statements is used to measure the students' language proficiency according to The Common European Framework of Reference (CEFR).

Figure 1: Competency-Based in Learning a Language

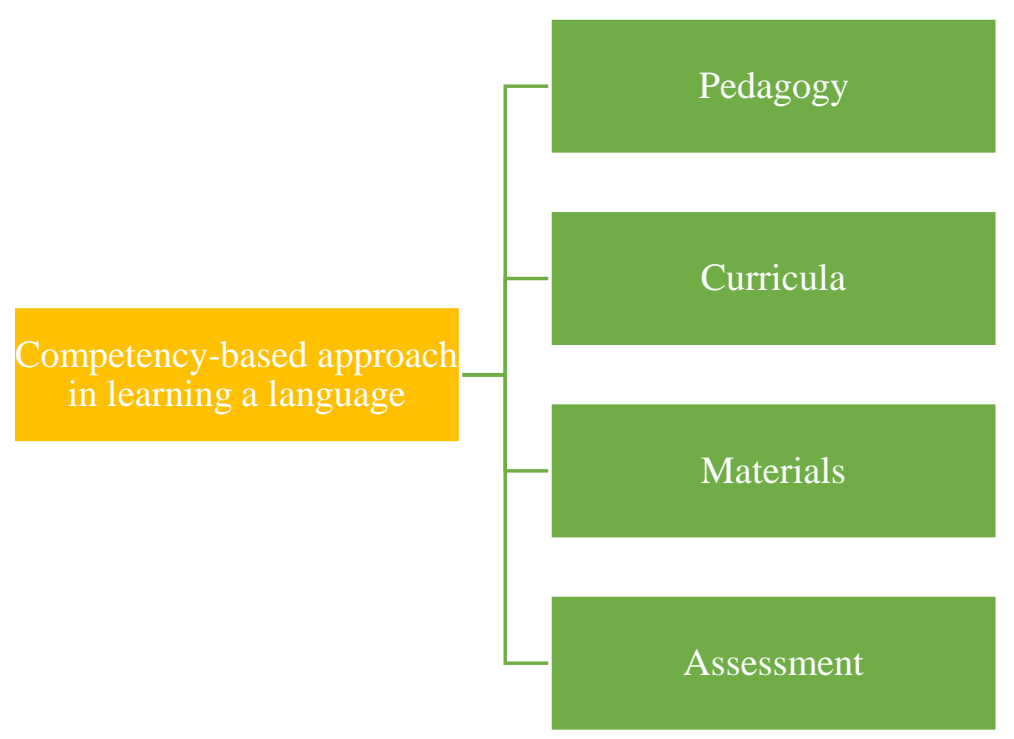

Source: Cambridge University Press (2021)

\section{Methodology}

This is a quantitative study using a descriptive research design. A survey was administered on students with learning difficulties in German language. Descriptive study analysis using frequency, mean and percentage tables was made using Statistical Package Software for Social Sciences, version 23. Based on the survey conducted among German Language students, 80 students were gathered in a WhatsApp group called Success German Course (SGC). In this WhatsApp group, the researcher distributes a questionnaire for the students to know their feedback regarding German Language Course. It also acts as a platform to measure student's performance as well as improve this course in future. Looking at the importance of the German language for this group of students and the importance of the third language proficiency for the graduate's employability, therefore this study was conducted. Of the 80 total German Language students that were recruited, 60 of them responded to this questionnaire.

The questionnaire was divided into 2 sections (Section A and B). Section A focuses on student's attitude towards the course, their understanding, self-motivation and other contributing factors which influence them in learning German Language. Section B focuses more on demographic data and their opinion regarding ways to improve their learning. Most of the respondents are females that are 45 and 15 males. All of them have attended German language courses in pursuing their dual-degree program. Most of them choose this course with their own choice. Besides that, most of them (87 percent) are from secondary school. 


\section{Result}

From this study, there are three main factors which contribute to student's success in German language course. There are also other minor contributing factors which include time frame of the course, personal problem and learning environment also play a role in determining the success.

\section{Attitude Towards the Course}

Figure 2 reveals the student's attitude towards German Language Course. Based on the Figure 2, most of the students can pay their attention during class. 37 out of 60 students fairly give attention in the class, while 13 of them answered satisfactorily and the remaining 10 can pay attention excellently. Unfortunately, the findings also showed that most of the students do not ask questions when they don't understand during the teaching session. 48 out of 60 students did not ask questions during the class. The issue of passivity among students might further complicate the situation in mastering a foreign language. Thus, it is vital for teachers to search for recent teaching practices in integrating critical thinking with the German course so that more can be done to improve the current situation. Pertaining to class attendance and punctuality, most of the students have good attendance and punctuality, where 12 out of 60 have satisfactory attendance and 48 of them have good attendance. About more than half of the students (43 out of 60) showed a good relationship with the teacher. Most of the students, where 58 out of 60 have a good interest in German Language course.

Figure 2: Student's attitude towards the course

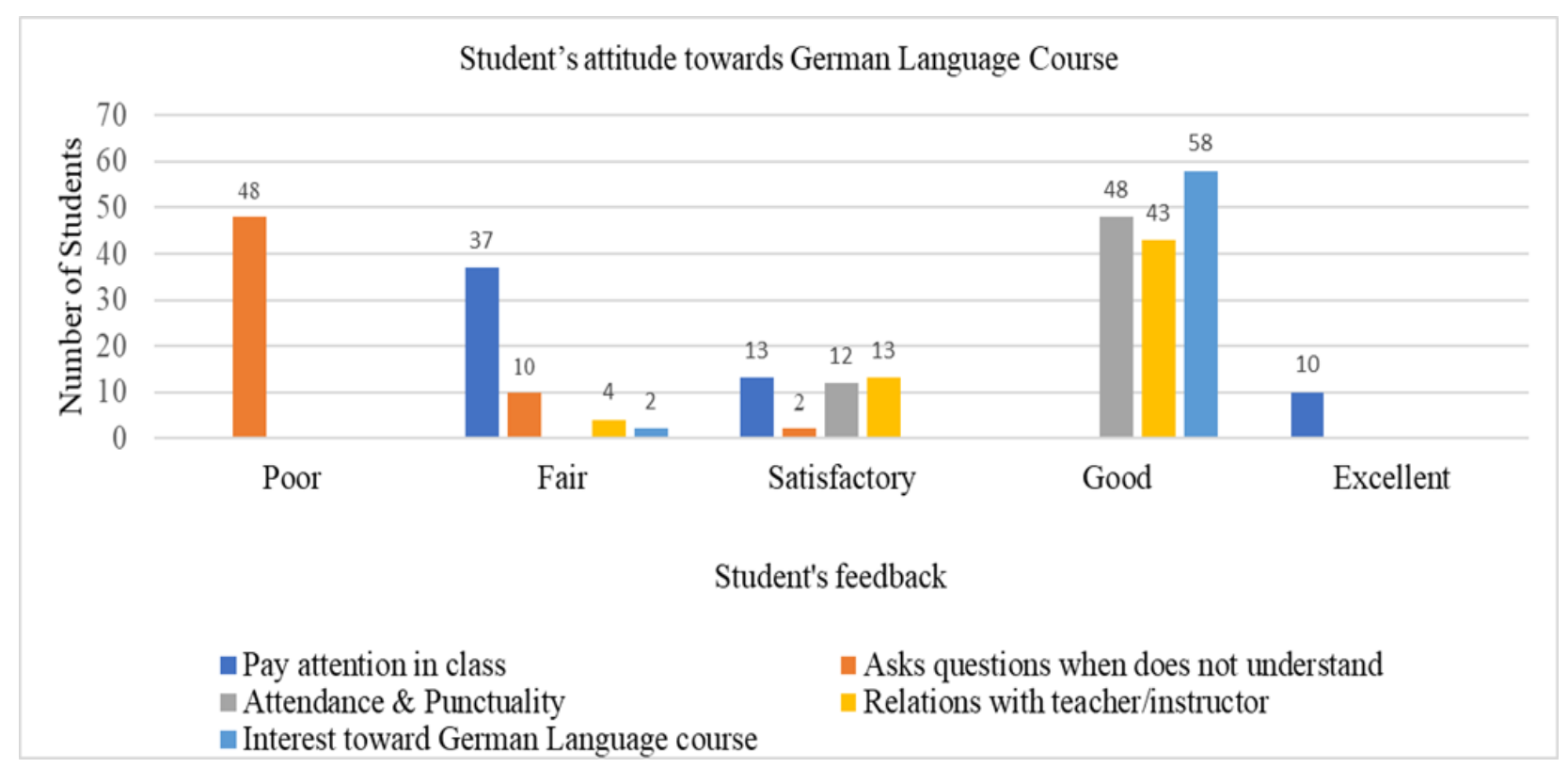

In language learning, Gardner (1985) finds attitudes to be components of motivation. Meanwhile, Wenden (1991) suggested a wider description of the term "attitudes," revealing that attitudes are made up of three components: cognitive, affective, and behavioural. The views, thoughts, or perceptions about the object of the attitude make up a cognitive component. The affective refers to one's feelings and emotions toward an object, whether they are 'likes' or 'dislikes,' 'with' or 'against.' Finally, the behavioural component refers to one's consisting actions or behavioural intentions towards the object. Study done by al-Tamimi and Munir (2009) revealed that student's attitude is one of the important predictors in determining student's success to master the foreign language. The good attitudes that can be highlighted in the respondents involved in this study are paying attention in the class, showing interest in the class, be punctual and have a good record of attendance as well as having a good relationship with lecturer. 


\section{Understanding Toward the Course}

Another aspect that we see in this questionnaire is the students' understanding of the course (refer to Figure 3). Most of them can understand the class materials that were given to them. Total of 45 out of 60 students answered as good and excellent in their feedback. In addition, most of them are able to understand their teaching and lessons very well. 9 out of 60 students have no problem in understanding teaching and lessons. Other than that, about 4 out of 60 students did not understand the tasks that were given to them. They also did not understand the course's needs. Meanwhile, more than half of the students stated that they do not understand the course's importance.

Figure 3: Student's understanding toward course

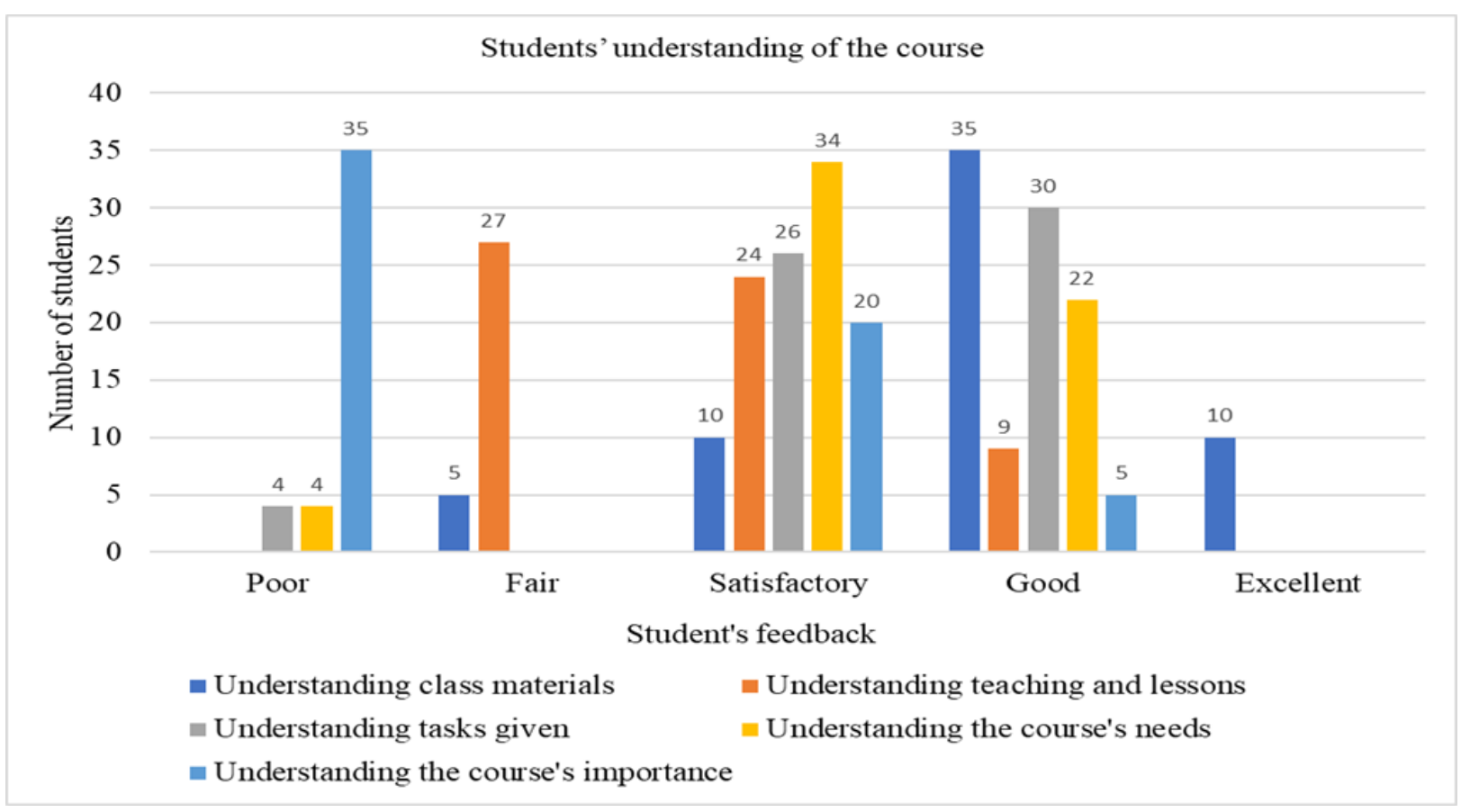

Nevertheless, their achievement in this regard needs to be applauded since it was understood that they had never registered for any German courses. They registered for the course due to their interest perhaps in going to German. Their negligence as in not asking their teachers of the tasks that were assigned to them needed to be looked further into since it was not clear the reasons of why they did so. To a certain extent, this result may be explained by the fact that Malaysians are of high-context culture. Shofner (n.d) states that a society with high context focuses on the underlying context, meaning, and tone when they communicate with others. It is not just the words that are being communicated but their non-verbal gestures also need to be considered to understand the messages that a particular person is conveying.

This finding showed that there were major issues that are required to be addressed for the improvement of the course which include students did not understand the task given, they did not get the requirement of the course, and they did not have the importance knowledge of the course. All these were related to one major issue in which they do not ask questions in class. Since the survey was only conducted among the students, it was not known for certain that the problem was with them or with the teachers. Nevertheless, asking questions is important in the teaching and learning process as reported by Almeida (2011) who stated that many teachers were not aware of the importance of classroom questioning. They also do not know whether students understand what they are teaching, which leads to learning issues in class. As a result, a pre-requisite is required to enroll in this program. An entrylevel test needs to be administered to select students who are eligible for the program as it will help the students to excel in the program before going to German. 


\section{Self-Motivation Toward the Course}

In this study, student's self-motivation and attitude towards the course were also analyzed. Based on the figure 4 as below, more than half of the students (40 out of 60) agree that the German Language Course will help them to achieve their goals. However, some of them (15 out of 60) do not know what the skills and knowledge are needed to learn the German Language. Figure 4 also revealed that only a few of the students (4 out of 60) feel that they are not in charge of their own failure and they are not willing to learn from it due to lack of motivation. Despite that, most students are eager to learn the German Language course and they are aware of the learning opportunities that are around them. For students who took the responsibility to be successful in this program, the results were likely to be related to their self-motivation. They were motivated to learn foreign languages due to their intrinsic motivation.

Figure 4: Student's Motivation toward the course

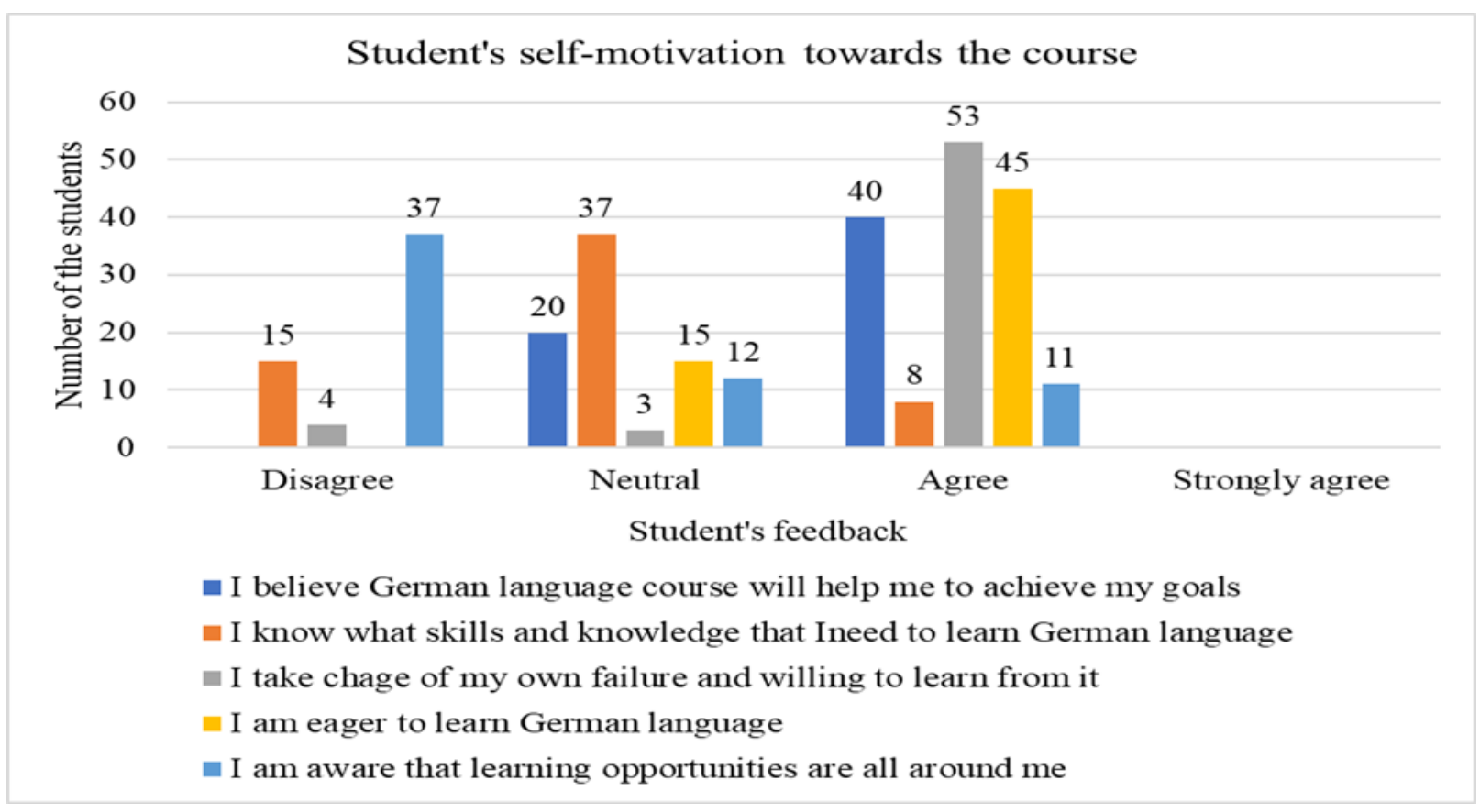

This finding is consistent with the study done by Zubairi and Sarudin (2009) among undergraduate students studying in UiTM indicate the student's interest and motivation in learning foreign languages are related to their ability in speaking and reading the language. They were also students reported to be interested in learning about other peoples' cultures. Nevertheless, concerning intrinsic motivation, the finding of Zubairi and Sarudin (2009) also stated that there is a need to outline the compulsory foreign language requirements in order to promote intrinsic motivation among students as well as planning for the content and methods of classroom teaching to meet the students' learning as it enables them to increase their motivation in learning. This reflects in the current study that there is a need for students to enhance their learning skills.

The learning of language requires students to learn four language's skills namely writing, speaking, reading and listening. According to Education Corners (2020), these skills can be learned and acquired as per below;

Table 1: language skill and component

\begin{tabular}{ll}
\hline Language skill & Component \\
\hline Listening & learn the art of listen for meaning \\
& learn to listen when you are speaking
\end{tabular}




\begin{tabular}{ll}
\hline Speaking & Focus on accuracy \\
& Learn how to write correct sentence structure \\
& Practice speaking \\
& Understand grammar \\
Reading & Read for meaning \\
& Read and re-read \\
& Understand grammar before writing \\
Writing & Pay attention to sentence structure and spelling
\end{tabular}

Source: Education Corners (2020)

Having outlined the idea to acquire the language skills, it is also important to review the curriculum of the German language. It is necessary to find suitable criteria to meet the needs, interests and abilities of students in certain language course offered in the university (Thaliyil, n.d.). Revisiting the curriculum is also necessary to identify suitable teaching methods and contents and at the same time remove unnecessary units in the syllabus.

\section{Minor Contributing Factor Toward the Course}

Figure 5 showed that almost all the students (51 out of 60 ) admitted that they do not have enough time to study. Only a few of them (6 out of 60) agreed that they have a good learning environment. Based on literatures cited in Kiatkheeree (2018), learning environment can be categorised into three broad aspects, which includes physical environment (such as materials, building, or classroom), psychological environment (such as attitude and value), and academic environment (such as learning strategy or academic performance). Kiatkheree (2018) highlighted that for a conducive learning environment, universities should provide good classroom facility, ensure teaching quality, promote effective activity and continuously support lecturers with appropriate workload. This in turn assist learners in effective learning.

Figure 5: Other minor contributing factors in determining student's success in German Language Course

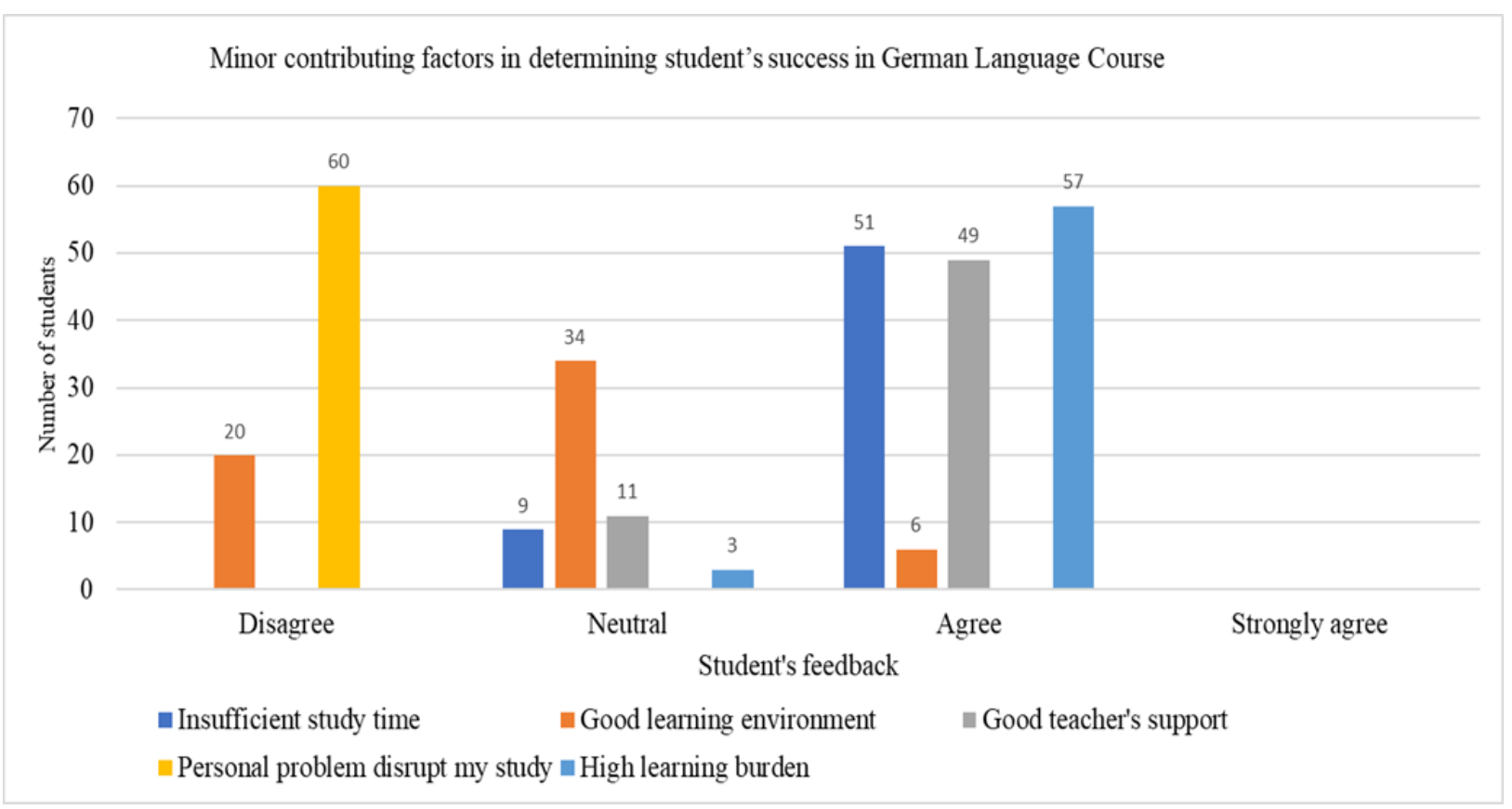


All respondents in this study disagreed that their personal problem disrupted their study. One intuitive explanation for this is that respondents have self-control and might be aware that exposure to stressful situations can affect learning and memory processes (Oflaz, 2019). Thus, other issues besides personal problems have a direct effect on foreign language learning. To illustrate this, almost all of them (57 out of 60) feel that they have a high learning burden and few stated that they have a fair task given (3 out of 60). Understanding the result, it can be inferred that students did not understand the requirements of the course and therefore failed to plan their time well when they study German language. This was a domino effect as when students were not able to understand the requirements of the course, they were unable to understand the importance of the course and the task that was given to them.

Based on the results, there is a concern with the student's difficulty to manage their learning time. It requires the revisit of Student Learning Time (SLT) by their respective teachers. It can be suggested that teachers need to carried out more revision regarding the course. At the same time, to ensure the success learning of German language among the learners, teachers need to provide more interactive teaching and learning approaches. It is suggested that role-playing, dramatization, discussion, brainstorming are some of the effective interactive method in the contemporary higher education (Yakovleva \& Yakovlev, 2014). Furthermore, students need to become a subject of educational activity in that dialogues among teachers, students and peers need to be encouraged (Kutbiddinova \& Eromasova, 2016). Hence, cognitive activities, searching and solving problematic tasks are the examples of dialogue-based activities that can be carried out among students at tertiary levels.

Other students stated that they have taken notes to improve their German vocabulary and grammar. They also mingle around with other German students and practice speaking German with them. One of them mentioned that YouTube and Google Search Engine was helpful to improve their learning. From the results it can be inferred that students need to acquire or perhaps enhance their study skills since they were not able to take effective notes for their grammar and vocabulary. Another suggestion that can be made concerning this result is to conduct intensive classes to the students who were low intermediate to low levels achievement. Self-access activities by requiring students to practice grammar and vocabulary exercises should be able to assist them in acquiring the language.

\section{Conclusion}

In conclusion, attitude and motivation plays a key role on the student's performance in the German Language Course. Most of the students have good attitude towards the course. However, most of them were quite passive and they rarely ask questions in class when they do not understand the lesson due to the time constraint. On the student's understanding of the course, we can conclude that most of them do not really understand the important elements that they need to concentrate on in this course. Most of them were highly motivated and want to improve themselves in the German Language Course, but their overall performance was underwhelming.

Other factors that we must consider is the time constraint. Interaction between teachers and students is important in mastering a foreign language, however students need to go beyond this and practice it with their family members, private tutors, community and others. Students who only have class time to study were more likely to just achieve a passing grade compared to students who have additional learning opportunities to practice and master additional languages. This may be an indicator for lecturer to re-evaluate the course. Some changes may need to be made to make sure that students are not burdened with too many things. Finally, lecturer also have to improve their performance and skills, so that all foreign language students can do better in their respective courses. There are certain limitations in this study. Firstly, the sample size taken in this study were very small involving only 60 students. If this study is being carried out again with a larger sample size, the results might differ from this study. An in-depth interview with both the students and lecturers is recommended for future research to enrich the data of the study. 


\section{References}

Ainol Madziah Zubairi \& Isarji $\mathrm{Hj}$ Sarudin. (2009). Motivation to learn a foreign language in Malaysia. GEMA Online Journal of Language Studies, 9(2).

Ainol Madziah Zubairi, Isarji Hj Sarudin \& Mohamad Sahari Nordin. (2007). A study of the effectiveness of foreign language programs in Malaysia. Proceedings in the 32nd Annual Congress of the Applied Linguistics Association of Australia, Making a Difference: Challenges for Applied Linguistics, University of Wollongong, 1-3 July, 2007.

Almeida, P. A. (2012). Can I ask a question? The importance of classroom questioning. ProcediaSocial and Behavioral Sciences, 31, 634-638.

Ambigapathy, P. (2002). English language teaching in Malaysia today. Asia Pacific Journal of Education, 22(2), 35-52. Retrieved 30 January, 2011 from http://www.tandfonline.com/doi/abs/10.1080/0218879020220205\#preview

Azar, A. S., \& Tanggaraju, D. (2020). Motivation in second language acquisition among learners in Malaysia. Studies in English Language and Education, 7(2), 323-333.

Azizi Ismail. (2018). Opening Ceremony Speech in 6th Malaysia International Conference on Foreign Language 2018. Auditorium Rashdan Baba. Universiti Putra Malaysia.

Azman Che Mat. (2010). Situasi pembelajaran bahasa asing di Institut Pengajian Tinggi: Perbandingan antara bahasa arab, bahasa mandarin dan bahasa perancis. ASEAN Journal of teaching and learning in Higher Education (AJTLHE), 2(2), 9-20.

Cambridge University Press. (2021). Competency-based Education. Retrieved on $1^{\text {st }}$ January 2021 from https://www.cambridge.org/us/cambridgeenglish/better-learning-archive/strongerresults/competency-based-education

De Burgh-Hirabe, R. (2019). Motivation to learn Japanese as a foreign language in an English speaking country: An exploratory case study in New Zealand. System, 80, 95-106. https://doi.org/https://doi.org/10.1016/j.system.2018.11.001

Dornyei, Z. (2002). Motivation in action: Towards a process-oriented conceptualisation of student motivation. British Journal of Educational Psychology, 70, 519-538.

Gardner, R. (1983). Learning another language: A true social psychological experiment. Journal of Language and Social Psychology, 2, 219-240.

Hazita Azman. (1999). Multilingual literacies in rural Malaysia: National goals and local practices [Unpublished Ph.D. thesis]. Graduate School of Education, The University of Western Australia.

Hidayatul Akmal Ahmad. (2018). Mahir bahasa asing buka lebih peluang kerja. Berita Harian Online. $\begin{array}{lllll}\text { Retrieved on } & \text { 1st } & \text { February } & 2021 & \text { from }\end{array}$ https://www.bharian.com.my/berita/nasional/2018/03/396747/mahir-bahasa-asing-buka-

Kutbiddinova, R. A., \& Eromasova, A. (2016). The use of interactive methods in the educational process of the Higher Education Institution. International Journal of Environmental and Science Education, 11(14), 6557-6572.

Leila Anjomshoa \& Firooz Sadighi. (2015). The importance of motivation in second language acquisition. International Journal on Studies in English Language and Literature (IJSELL). $3(2), 126-137$.

Lei, S. A. (2010) Intrinsic and extrinsic motivation: Evaluating benefits and drawbacks from college instructors' perspectives. Journal of Instructional Psychology, 37(2), 153-160.

Matters, E. C. E. (2020). How To Study a Foreign Language. Retrived on $2^{\text {nd }}$ January 2021 from https://www.educationcorner.com/foreign-language-study-skills-guide.html

Normazidah Che Musa, Koo Yew Lie \& Hazita Azman (2012). Exploring english language learning and teaching in Malaysia. GEMA Online Journal of Language Studies, 12(1), Special Section, $35-51$.

Oflaz, A. (2019). The Effects of anxiety, shyness and language learning strategies on speaking skills and academic achievement. European Journal of Educational Research, 8(4), 999 - 1011.

Oga-Baldwin, W. L. Q., Nakata, Y., Parker, P., \& Ryan, R. M. (2017). Motivating young language learners: A longitudinal model of self-determined motivation in elementary school foreign language classes. Contemporary Educational Psychology, 49, 140-150. https://doi.org/https://doi.org/10.1016/j.cedpsych.2017.01.010

Pintrich, P. R. (2000). Multiple goals, multiple pathways: The role of goal orientations in learning and 
achievement. Journal of Educational Psychology, 92, 544-555.

Siti Khasinah. (2014). Factors influencing second language acquisition. Englisia, 1(2), 256-269.

Shofner, K. (n.d). Communicating in high context vs. low context culture, Available at https://www.unitedlanguagegroup.com/blog/communicating-high-context-vs-low-contextculture

Thaliyil, B. (n.d.). Need for revision, renewal and reification of curriculum. https://www.slideshare.net/bavijesh/need-for-curriculum-revision\#: :text=NEED $\quad$ FOR REVISION IN CURRICULUM,content\%2C new knowledge and practices.

The Ministry of Higher Education. (2007). The National Higher Education Strategic Plan beyond 2020. The Ministry of Higher Education Malaysia Press.

Ulfa, M., \& Bania, A. S. (2019). EFL student's motivation in learning English in Langsa, Aceh. Studies in English Language and Education, 6(1), 163-170.

Usman, B., Silviyanti, T. M. \& Marzatillah. (2016). The influence of teacher's competence towards the motivation of students in learning English. Studies in English Language and Education, $3(2), 134-146$.

Wenden, A. (1991). Learner strategies for learner autonomy. London: Prentice Hall.

Yakovleva, N. O., \& Yakovlev, E. V. (2014). Interactive teaching methods in contemporary higher education. Pacific Science Review, 16(2), 75-80. https://doi.org/https://doi.org/10.1016/j.pscr.2014.08.016

Zubairi, A. M., \& Sarudin, I. H. (2009). Motivation to learn a foreign language in Malaysia. GEMA Online Journal of Language Studies, 9(2). 